\title{
Ueber Gesetzeskonkurrenz
}

auf dem

Gebiete des Strafreehts.

$$
\text { Von }
$$

\section{Dr. Otto Pflaum.}

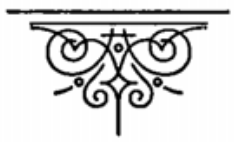

München.

J. Schweitzer Verlag (Jos. Eichbichler) 1898. 
